\title{
Enterprise Value Generators in the Building Industry
}

\author{
Marek Vochozka ${ }^{1}$ and Veronika Machová, ${ }^{*}$ \\ ${ }^{1}$ Institute of Technology and Business, School of Expertness and Valuation, Okružní 517/10, 37001 \\ České Budějovice, Czech Republic \\ ${ }^{2}$ University of Economics, Faculty of Business Administration, Nám. W. Churchilla 4, \\ 13067 Praha 3 - Žižkov, Czech Republic
}

\begin{abstract}
Value generators mark factors that influence the given enterprise's success most. Thus, they refer to activities and abilities that increase profitability, decrease risk, and support the company's growth. The aim of this contribution is to identify value generators in a building enterprise. The main presumption, however, is that the enterprise value will be measured by the EVA Equity indicator (Economic Value Added for the shareholders - owners). Data to be analysed come from the Albertina database. They include complete financial statements of building enterprises that operated on the market between 2006 and 2015. The data is organized into a table the EVA Equity in each enterprise is calculated per each year of its operation on the market. The table is subsequently imported into the Statistica software which searches for the extent to which the EVA Equity indicator is dependent on the individual items of financial statements. The result is a created adequate methodology and identification of value generators in building industries from 2006 to 2015 in the Czech Republic. The following variables are marked as the most significant: economic growth per current accounting period, equity, bank loans and bailouts, trade receivables, and current assets.
\end{abstract}

Key words: value generators, EVA Equity, enterprise value, artificial neural networks

\section{Introduction}

Value generators are factors that have the greatest impact on the company's success, and are specific for different industry branches and enterprises [1]. A value generator may be described as an activity or an ability that adds value to a product, service, brand or the enterprise itself. Specifically, value generators refer to activities or abilities that increase profitability, decrease risk and support growth in accordance with strategic aims. Such aims may include a growing shareholder value, competition advantage and customer determination [2].

The main aim of every business activity is to create value for the owner. With regard to the complexity of nowadays organizations and the circumstances of growing customer

\footnotetext{
* Corresponding author: machova@mail.vstecb.cz
} 
demands in which they compete, it is necessary for the company aims focused on value to be efficiently managed at all organization levels. A well considered strategy may be only successful if the company aims are transparent, comprehensible for workers, and controllable [3].

Nowadays, most global markets are being globalized, and competition is becoming more exponential. Companies always try to be as competitive as possible. They use different tools to do so. One of them is modern manager style called 'Value-Based Management'. Its aim is to focus on creation of values for the company. Establishing this type of management is not easy because the company has to identify the managers correctly, as they are the ones responsible for value creation in the company [4].

Value-Based Management (VBM) may be defined as an integrated managing approach based on several elements including managing systems [5]. Specifically, VBM should offer a general frame via which managers may define, implement and promote strategies when creating values within a company, and provide the owners with resources for monitoring and harmonizing manager actions [6]. The key VBM element is metrics based on values that combine costs on invested capital and company profitability [7]. These metrics and a related set of linked value controls are meant to replace traditional accounting measures, such as key financial indicators in a company, and serve as the main company performance indicators [8]. Based on this, metrics based on values should contribute to creating strategies, allocating sources and determining financial aims, and thus harmonizing the inner aims with creating shareholder value [9]. Meanwhile, integration of metrics based on values within a compensation system of enterprises should still support harmonization of well motivated managers [10].

Nowadays, knowledge assets are generally understood as organization sources that play a key role in creating the company's value. Mechanisms through which these assets participate in creating a value, are still not well known. This contribution draws on this need and suggests a model for identifying knowledge assets of an enterprise that significantly contribute creation of values. The model is basically designed as a cognitive map, and it draws on the combination of knowledge gathered from literature about strategic management [11].

Lately, more and more experts believe that the main aim of a stable enterprise is mainly growth of value for owners, shareholders. There are several options of measuring such growth. The EVA Economic Value Added is a very useful and significant tool for judging enterprise performance. It combines such factors as economy, accounting, and market information [12]. According to Morad and Balu [13], this indicator tries to express the company's real economic profit. Its significant advantage, as opposed to usual approaches, is the ability to evaluate the enterprise's economic performance comprehensively, and take into account the amount of investment risk [14]. According to Kollar and Klieštik [15], the EVA indicator represents the most advanced tool for measuring enterprise performance based on the principle of value management. According to Bluszcz and Kijewska [16], the EVA indicator depends on the amount of capital invested, and the economic dimension. Frank and Shen [17] claim that economic dimension is expressed via the weighted average costs on capital, and the return on invested capital.

The aim of this contribution is to identify the generators of a building enterprise value.

However, the assumption is that the enterprise value will be measured via the EVA Equity indicator.

\section{Data and Methods}

Data meant for analysis will come from the Albertina database. Building enterprises that operated on the market during 2006 to 2015 will be concerned. In total, the dataset will 
contain records of 65,656 enterprises. Data of their complete financial statements will be available (except attachments). That means that we will use balance sheet, profit and loss sheet, and statement of cash flow data. The data will be organized into a table which will be lined according to companies and the years of their activity. The columns will then contain individual information from Financial Statements.

In the next step, the value of Economic Value Added for shareholders (owners) will be calculated for every enterprise in each year of its operation on the market, i.e. within the parameters of EVA Equity.

This is first presumed by the Weighted Average Costs of capital [18]:

$$
W A C C=r_{f}+r_{L A}+r_{\text {entreprenairship }}+r_{\text {FinStab }}
$$

Where:

WACC

$r_{f}$

$r_{L A}$

$r_{\text {entrepreneurship }}$

$r_{\text {FinStab }}$ represents the Weighted Average Costs of Capital, Risk-free yield, function of indicators characterizing the size of the enterprise, function of indicators characterizing the creation of production power, function of indicators characterizing relationships between enterprise property and sources of their financial backing.

Subsequently, the value of alternative rate of equity will be stated [18]:

$$
r_{e}=\frac{W A C C * \frac{U Z}{A}-(1-d) * \frac{U}{B L+B} *\left(\frac{U Z}{A} * \frac{E}{A}\right)}{\frac{E}{A}}
$$

Where:

WACC Weighted Average Costs of capital,

UZ Money Sources (Corrupt Sources) (Equity and Interest-bearing Loan Capital),

A Assets,

E Equity,

BL Bank Loan,

B Bonds,

$\frac{U}{B L+B} \quad$ Interest Rate. The 'I' mark may also be used,

$\mathrm{d} \quad$ Income Tax Rate (in the previous models the ' $\mathrm{t}$ ' mark was used).

The Economic Value Added for shareholders will be derived from the following relationship [18]:

$$
\text { EVA Equity }=\left(R O E-r_{\theta}\right) * V K
$$

Where:

ROE represents Return on Equity.

Subsequently, the table will be imported into the DELL Statistica Software, version 12. We are going to look for the extent to which the EVA Equity indicator is dependent on the individual items of financial statements. 
We will use the data mining tool, automated neural networks (ANN). We will deal with regression. EVA Equity will be determined the dependent variable. Financial statement data will represent the independent variables. The data file will be divided into three sets training, testing and validational. The first group will contain $70 \%$ of input data. Based on the training data set neural structures will be generated. The left over two data sets $15 \%$ will be always left. Both groups will serve to verify the reliability of the found neural structure, respectively the found model. We will generate 1,000 neural networks. Out of them, 5 proving the best characteristics, will be kept ${ }^{1}$. The hidden layer will contain a minimum of two neurons, a maximum of 150 . In case of a radial basic function, the hidden layer will contain a minimum of 21 neurons, 80 the most. For a multilayer perceptron network, the following distributional functions will be considered in the hidden and in the output layer:

- Linear,

- Logistical,

- Atanh,

- Exponential,

- Sinus.

Neural networks predicting the EVA Equity based on input data will be the result. The model will take into account only such variables that will influence the resulting value of EVA Equity in reality. We will choose such a neural structure that will describe the relationship as correctly as possible (i.e. proving the best performance in the training, testing and validational data set, minimal error in each data set, and a clear economic interpretation). We will be subsequently interested in the value of neurons entering a network chosen in that way. Moreover, we will carry out sensitivity analysis to determine which variables enter the calculation and which of them influence the result significantly, at the same time. Value generators will be the result of sensitivity analysis.

\section{Results}

Table No.1 offers five of the best generated and preserved neural networks.

Table 1. Neural Networks with the best characteristics

\begin{tabular}{|l|l|c|c|c|c|c|c|l|l|l|}
\hline Network & $\begin{array}{c}\text { Training } \\
\text { Perf. }\end{array}$ & $\begin{array}{c}\text { Testing } \\
\text { Perf. }\end{array}$ & $\begin{array}{c}\text { Valid. } \\
\text { Perf. }\end{array}$ & $\begin{array}{c}\text { Training } \\
\text { Error }\end{array}$ & $\begin{array}{l}\text { Testing } \\
\text { Error }\end{array}$ & $\begin{array}{l}\text { Valid. } \\
\text { Error }\end{array}$ & $\begin{array}{c}\text { Training } \\
\text { Algorithm }\end{array}$ & $\begin{array}{l}\text { Error } \\
\text { Function }\end{array}$ & $\begin{array}{l}\text { Hidden Layer } \\
\text { Act. }\end{array}$ \\
\hline 1 & $\begin{array}{l}\text { MLP } \\
28-19-1\end{array}$ & 0.987825 & 0.979665 & 0.98839 & 5810288 & 8348213 & 6624405 & BFGS 59 & $\begin{array}{l}\text { Square } \\
\text { Sum. }\end{array}$ & Exponential \\
\hline 2 & $\begin{array}{l}\text { MLP } \\
28-10-1\end{array}$ & 0.992142 & 0.976071 & 0.98913 & 3762468 & 9837310 & 6252567 & BFGS 96 & $\begin{array}{l}\text { Square } \\
\text { Sum. }\end{array}$ & Tanh \\
\hline 3 & $\begin{array}{l}\text { MLP } \\
28-21-1\end{array}$ & 0.990369 & 0.979875 & 0.987803 & 4605288 & 8283818 & 6963926 & BFGS 131 & $\begin{array}{l}\text { Square } \\
\text { Sum. }\end{array}$ & Logistical \\
\hline 4 & $\begin{array}{l}\text { MLP } \\
28-14-1\end{array}$ & 0.989948 & 0.977133 & 0.987428 & 4803759 & 9439238 & 8521111 & BFGS 74 & $\begin{array}{l}\text { Square } \\
\text { Sum. }\end{array}$ & Exponential \\
\hline 5 & $\begin{array}{l}\text { MLP } \\
28-17-1\end{array}$ & 0.987636 & 0.978024 & 0.987556 & 5904161 & 9012839 & 7575515 & BFGS 65 & $\begin{array}{l}\text { Square } \\
\text { Sum. }\end{array}$ & Exponential \\
\hline
\end{tabular}

The table clearly proves that multilayer perceptron networks have the preserved, thus the best characteristics. In all cases Quasi-Newton was used as a training algorithm, nevertheless, always in its different variant. Smallest square method was considered an error function. The hidden neuron layer is in case of preserved neural networks activated

\footnotetext{
${ }^{1}$ We will get oriented via the smallest squares method. Network generation will end if there is no improvement, i.e. a decrease in value when adding the squares. Thus, we will keep those neural structures where the total of square residues compared to the real gold development will be the lowest (in an ideal case, equal to zero).
} 
via exponential function, respectively via hyperbolic tangens and logistical function. Logistical function is the output activation one. Number of neurons in the first layer is very promising information. In all cases, there are 28 neurons. If all of them are represented by the same variables, we may boldly identify, with a relative high exactness, the enterprise value generators in building industry.

Relevance of generated networks is given by Table No. 2 .

Table 2: Performance in Preserved Neural Networks

\begin{tabular}{|l|c|c|c|}
\hline Neural Network & Training & Testing & Validational \\
\hline 1.MLP 28-19-1 & 0.987825 & 0.979665 & 0.98839 \\
\hline 2.MLP 28-10-1 & 0.992142 & 0.976071 & 0.98913 \\
\hline 3.MLP 28-21-1 & 0.990369 & 0.979875 & 0.987803 \\
\hline 4.MLP 28-14-1 & 0.989948 & 0.977133 & 0.987428 \\
\hline 5.MLP 28-17-1 & 0.987636 & 0.978024 & 0.987556 \\
\hline
\end{tabular}

In the given table we may observe the performance of individual networks in all data sets (training, testing, and validational). In the optimal situation, we are looking for the highest performance value (correlational coefficient), and at the same time an equal value for all data sets. Probably the best characteristics are offered by the first network, MLP 2819-1. It is however necessary to add that differences between individual networks are minimal.

For a better guess of a correct result, prediction parameters carried out with the use of individual networks are given in Table No. 3.

Table 3. Prediction Parameters

\begin{tabular}{|c|c|c|c|c|c|}
\hline Prediction Parameter & $\begin{array}{c}1 . \\
\text { MLP } \\
28-19-1\end{array}$ & $\begin{array}{c}2 . \\
\text { MLP } \\
28-10-1\end{array}$ & $\begin{array}{c}3 . \\
\text { MLP } \\
28-21-1\end{array}$ & $\begin{array}{c}4 . \\
\text { MLP } \\
28-14-1\end{array}$ & $\begin{array}{c}5 . \\
\text { MLP } \\
28-17-1\end{array}$ \\
\hline Minimal Prediction (Training) & -625821 & -593672 & -565909 & -618678 & -627985 \\
\hline Maximal Prediction (Training) & 1285241 & 1296644 & 1280179 & 1310115 & 1285661 \\
\hline Minimal Prediction (Testing) & -439848 & -420398 & -485825 & -472289 & -419033 \\
\hline Maximal Prediction (Testing) & 716318 & 773790 & 712872 & 731896 & 741961 \\
\hline Minimal Prediction (Validational) & -534500 & -489643 & -487837 & -488074 & -540623 \\
\hline Maximal Prediction (Validational) & 931984 & 966569 & 919711 & 962717 & 932213 \\
\hline Minimal Residues (Training) & -151009 & -79944 & -115456 & -118709 & -123061 \\
\hline Maximal Residues (Trénovací) & 158204 & 114905 & 122328 & 139520 & 165594 \\
\hline Minimal Residues (Testing) & -206335 & -221582 & -192218 & -215316 & -199480 \\
\hline Maximal Residues (Testing) & 60896 & 60488 & 106207 & 69333 & 64274 \\
\hline Minimal Residues (Validational) & -171069 & -133646 & -204284 & -166636 & -182821 \\
\hline Maximal Residues (Validational) & 68236 & 81589 & 68456 & 100494 & 72700 \\
\hline Minimal Standard Residues (Training) & -63 & -41 & -54 & -54 & -51 \\
\hline Maximal Standard Residues (Training) & 66 & 59 & 57 & 64 & 68 \\
\hline Minimal Standard Residues (Testing) & -71 & -71 & -67 & -70 & -66 \\
\hline Maximal Standard Residues (Testing) & 21 & 19 & 37 & 23 & 21 \\
\hline Minimal Standard Residues (Validational) & -66 & -53 & -77 & -57 & -66 \\
\hline Maximal Standard Residues (Validational) & 27 & 33 & 26 & 34 & 26 \\
\hline
\end{tabular}

Even Table No. 3 shows clearly that differences in prediction are minimal. This is proven not only by the extreme prediction values, but also the extreme residue values.

Further, sensitivity analysis was carried out. Results of the analysis are given in Table No. 4. 
Table 4. Sensitivity Analysis

\begin{tabular}{|c|c|c|c|c|c|c|}
\hline Indicator & $\begin{array}{c}1 . \\
\text { MLP } \\
28-19-1 \\
\end{array}$ & $\begin{array}{c}2 . \\
\text { MLP } \\
28-10-1 \\
\end{array}$ & $\begin{array}{c}3 . \\
\text { MLP } \\
28-21-1\end{array}$ & $\begin{array}{c}4 . \\
\text { MLP } \\
28-14-1 \\
\end{array}$ & $\begin{array}{c}5 . \\
\text { MLP } \\
28-17-1 \\
\end{array}$ & Average \\
\hline $\begin{array}{l}\text { Economic Result per } \\
\text { Accounting Period }(+/-)\end{array}$ & 45,52534 & 57,62013 & 54,98645 & 47,86791 & 43,15851 & 49,83167 \\
\hline Equity & 3,096897 & 3,525898 & 5,279423 & 3,107585 & 3,478305 & 3,697622 \\
\hline Bank Loans and Bailout & 2,592221 & 3,381039 & 3,513716 & 2,641688 & 2,582952 & 2,942323 \\
\hline Trade Receivables & 1,745256 & 1,761609 & 2,929951 & 1,689505 & 1,755744 & 1,976413 \\
\hline Fixed Assets & 1,307376 & 3,434348 & 1,739905 & 1,746764 & 1,189961 & 1,883671 \\
\hline Current Assets & 1,285155 & 3,014548 & 1,373655 & 1,255774 & 1,292558 & 1,644338 \\
\hline Short-term Receivables & 1,582573 & 1,572459 & 2,128731 & 1,253316 & 1,516588 & 0733 \\
\hline Operating Profit & 1,539484 & 1,580329 & 1,939547 & 1,252003 & 1,512833 & 1,564839 \\
\hline Total Obligations & 1,373689 & 1,26703 & 1,993261 & 1,538607 & 1,301354 & 1,494788 \\
\hline Long-term Receivables & 1,443037 & 1,684167 & 1,475288 & 1,326547 & 1,472512 & 1,48031 \\
\hline Tangible Fixed Assets & 1,611922 & 1,462031 & 1,185565 & 1,288986 & 1,607434 & 1,431187 \\
\hline Foreign Sources & 1,78316 & 1,238692 & 1,181723 & 1,678969 & 1,19326 & 1,415161 \\
\hline Personal Costs & 1,070623 & 1,112373 & 1,528621 & 1,06989 & 1,05861 & 1,168023 \\
\hline Value Added & 1,069547 & 1,289792 & 1,273848 & 1,083258 & 1,083973 & 0084 \\
\hline $\begin{array}{l}\text { Costs on Sales + Power } \\
\text { Consumption }\end{array}$ & 81 & 1,2096 & 1,13 & 1,083609 & 1,024377 & 82 \\
\hline Power Consumption & 1,048284 & 1,158429 & 1,203669 & 1,027318 & 1,048093 & 1,097159 \\
\hline $\begin{array}{l}\text { Consumption of } \\
\text { Material and Energy }\end{array}$ & 1,051657 & 1,172924 & 1,108193 & 1,074561 & 1,052695 & 1,092006 \\
\hline Total Assets & 1,058739 & 1,198038 & 1,073814 & 1,027691 & 1,089817 & 1,08962 \\
\hline Current Assets & 1,048995 & 1,086747 & 1,11206 & 1,05345 & 1,103385 & 1,080927 \\
\hline $\begin{array}{l}\text { Long-term Intangible } \\
\text { Assets }\end{array}$ & 1,145869 & 0,985621 & 1,064498 & 1,137256 & 1,058307 & 1,07831 \\
\hline Supplies & 014047 & 1,102265 & 1,181804 & 1,052269 & 1,038923 & 77862 \\
\hline Basic Capital & 1,095442 & 1,010118 & 1,077835 & 0,987304 & 1,133611 & 1,060862 \\
\hline Trade Obligations & 1,121967 & 1,024943 & 1,072587 & 1,070067 & 1,013501 & 1,060613 \\
\hline Business Margin & 1,034675 & 1,008112 & 1,170859 & 0,997513 & 1,036753 & 1,049582 \\
\hline $\begin{array}{l}\text { Sale Revenue of Own } \\
\text { Products and Services } \\
\end{array}$ & 1,066979 & 1,085189 & 1,011392 & 1,048065 & 0,996401 & 1,041605 \\
\hline $\begin{array}{l}\text { Sale Revenue of Sold } \\
\text { Goods and Performance }\end{array}$ & 1,040813 & 1,034926 & 1,029347 & 1,03945 & 1,00828 & 1,030563 \\
\hline Performance & 0,999527 & 1,070207 & 1,062063 & 0,995275 & 1,007639 & 1,026942 \\
\hline $\begin{array}{l}\text { Operating Production } \\
\text { Revenues }\end{array}$ & 1,001808 & 1,078419 & 1,006702 & 1,013017 & 0,993135 & 1,018616 \\
\hline
\end{tabular}

The table shows that the same variables entered the calculation in all cases. Although the order of importance differs in individual networks, the difference is not too significant. First, there is, logically (and as expected), economic result. Further, Equity appears (again as expected), bank loans and bailout, trade receivables, long-term assets, and current assets. Other positions of this notional rank have been taken by variables that do influence the value creation in an enterprise, but their meaning is not too big.

\section{Conclusion}

The aim of this contribution has been to identify value generators within a building enterprise. An adequate methodology was created, and value generators within building enterprises from 2006 to 2015 were generated for the Czech Republic. In total, 28 quantities were identified, entering the process of enterprise value creation, which is measured via the EVA Equity indicator.

The following variables were identified as the most significant: the profit or loss for the current accounting period, equity, bank loans and bailout, trade receivables, long-term assets and current assets. 
Result potential is important. Another research may follow. At this point, it is suitable to identify the amount of individual variables' influence on the EVA Equity, and at the same time to determine the relationship of these variables towards EVA Equity. In the following step it is suitable to decompose the partial indicators, and incorporate them within the tactical and operative aims of the given enterprise. The strategic aim is given. It is the growth of value for shareholders.

\section{References}

1. B. Andrea, B Coulson, C. Professor, A. Dr, R. Hogan, J. D. Evans, Does the strategic alignment of value drivers impact earnings persistence? Sustainability Accounting. Management and Policy Journal, 6(3), 374-396 (2015)

2. V. Kazlauskiene, C. Christauskas, Business Valuation Model Based on the Analysis of Business Value Drivers. Engineering Economics, 57(2), 23-31 (2008)

3. I. Zareba, Strategic and financial drivers of business value creation. Business and nonprofit organizations facing increased competition and growing customers' demands, Muszyna, Poland, 403-416 (2014)

4. J. Šalaga, Value-based management and value drivers in world market. Proceedings of the $15^{\text {th }}$ International Scientific Conference Globalization and its socio-economic consequences, Rajecke Teplice, Slovakia, $743-747$ (2015)

5. M. Burkert, R. Lueg, Differences in the sophistication of Value-based Management The role of top executives. Management Accounting Research, 24(1), 3-22 (2013)

6. M. C. Daraban, An empirical view on value theory and value-based management. $C B U$ International Conference Proceedings, 4, 26-34 (2016)

7. D. Ch. Ittner, D. F. Larcker, T. Randall, Performance implications of strategic performance measurement in financial services firms. Accounting, Organizations and Society, 28(7-8), 715-741 (2003)

8. V. Stehel, M. Vochozka, Company Management by Using INFA Method. Proceedings of the 12th International Academic Conference, (2014)

9. J. Šalaga, V. Berzáková, Summary and comparison of values indicators of value based management. Economic and management spectrum [Ekonomicko-manažerské spektrum], 8, 48-54 (2014)

10. S. Firk, S. Schrapp, M. Wolff, Drivers of value creation - The role of value-based management and underlying institutions. Management Accounting Research, 33, 42 60 (2016)

11. F. D. Sole, F., D. Carlucci, G. Schiuma, Mapping Intellectual Capital Dynamics to Identify Company's Value Drivers. Proceedings of the European Conference on Intellectual Capital, 423-434 (2009)

12. I. Issham, A. Samad, M. Fazilah, Y. S. HWA, A. A. Kamil, Economic value added (EVA) as a performance measurement for GLCs vs Non-GLCs: Evidence in Bursa Malaysia. Prague Economic Papers, (2), 168-179, (2008)

13. B. Morard, F. O. Balu, Developing a practical model for calculating the economic value added. Economic Computation and Economic Cybernetics Studies and Research, 3(3), 1-16 (2009)

14. V.Stehel, M. Vochozka, The analysis of the economical value added in transport. Nase More, Dubrovnik: University of Dubrovnik, 63(3), 185-188 (2016) 
15. B. Kollar, T. Kliestik, Approach in credit risk models. Proceedings of the 4th International Conference on Applied Social Science (ICASS 2014), 51, 150-155 (2014)

16. A.Bluszcz, A. Kijewska, Factors Creating Economic Value Added of Mining Company. Archives of Mining Sciences, 61(1), (2016)

17. M. Z. Frank, T. Shen, Investment and the weighted average cost of capital. Journal of Financial Economics, 119(2), 300-315 (2016)

18. I. Neumaierová, I Neumaier, Financial analysis of industry and construction in 2007 [Finanční analýza průmyslu a stavebnictví za rok 2007]. Analysis of the Ministry of Industry and Trade [Analýzy MPO], 1, 1-187 (2008) 